\title{
Alveolar Macrophages Release an Insulin-like Growth Factor I-Type Molecule
}

\author{
William N. Rom, Paul Basset, Gerald A. Fells, Toshihiro Nukiwa, Bruce C. Trapnell, and Ronald G. Crystal \\ Pulmonary Branch, National Heart, Lung and Blood Institute, National Institutes of Health, Bethesda, Maryland 20892
}

\begin{abstract}
Human alveolar macrophages, when activated, release a progression-type growth factor for fibroblasts that signals "competent" fibroblasts to replicate. The present study demonstrates that this growth activity is an insulin-like growth factor I (IGF-I)-type molecule. Partial purification of medium conditioned by activated alveolar macrophages using ion exchange and gel filtration chromatography revealed an IGF-I molecule as detected by an anti-IGF-I polyclonal antibody and that the specific activity of the progression-type growth activity tracked with the amount of IGF-I present. In a serum-free complementation test, the increase in fibroblast proliferation by alveolar macrophage IGF-I was reduced in a dose-response manner with an anti-IGF-I monoclonal antibody. The alveolar macrophage IGF-I displaced ${ }^{125}$ I-IGF-I from its receptor in a binding assay utilizing human lung fibroblasts and it stimulated type I IGF receptors purified from human lung fibroblasts to phosphorylate a tyrosine-containing artificial substrate. In contrast to the 7.6-kD serum IGF-I, gel chromatography revealed that the alveolar macrophage IGF-I had an apparent molecular mass of $26 \mathrm{kD}$, similar to other tissue IGF-Is. Alveolar macrophages expressed IGF-I mRNA transcripts as detected by solution hybridization using a ${ }^{32} \mathrm{P}$-labeled riboprobe complementary to exons I-II-III of the IGF-I gene. In the context of the known functions of the family of IGF-I molecules in cell growth, IGF-I released by activated alveolar macrophages may play a role in acute and chronic inflammatory disorders.
\end{abstract}

\section{Introduction}

Tissue macrophages, members of the mononuclear phagocyte system of bone marrow-derived cells present in most organs, are thought to play a central role in normal wound healing and pathologic tissue fibrosis by virtue of their ability to release a variety of polypeptide mediators that serve as growth factors for mesenchymal cells (1-8). In humans, most information regarding tissue macrophage production of mesenchymal growth factors relates to alveolar macrophages, a tissue macrophage easily accessible by bronchoalveolar lavage $(9,10)$. Human alveolar macrophages are known to be capable of expressing the genes for several defined growth factors including the c-sis gene (the $\beta$-chain of platelet-derived growth factor $\left.[P D G F]^{1}\right)$, fibronectin, interleukin $1-\beta$ and tumor necrosis

Address reprint requests to Dr. Rom, Pulmonary Branch NHLBI, Building 10, Room 6D03, National Institutes of Health, Bethesda, MD 20892.

Received for publication 15 July 1987 and in revised form 25 May 1988

1. Abbreviations used in this paper: AMDGF, alveolar macrophage-derived growth factor; IGF-I and II, insulin-like growth factors I and II; PDGF, platelet-derived growth factor.

The Journal of Clinical Investigation, Inc.

Volume 82, November 1988, 1685-1693 factor (11-21). Furthermore, in the fibrotic lung diseases such as idiopathic pulmonary fibrosis (IPF), alveolar macrophages are spontaneously releasing exaggerated amounts of PDGF and fibronectin, leading to the concept that the alveolar macrophage plays an important role in directing the exaggerated fibroblast accumulation in the alveolar walls that characterizes this disease $(10,13,15,22)$.

In the dual control model of the timing of growth factor action during the cell cycle of fibroblast proliferation, Pledger and co-workers $(23,24)$ developed the concept that fibroblasts require two signals to trigger growth, a "competence" signal acting early in $G_{1}$, and a later "progression" signal acting late in $G_{1}$ to stimulate the cell to synthesize DNA and proliferate. In regard to growth factors released by alveolar macrophages, PDGF and fibronectin are capable of serving as "competence" factors for mesenchymal cells $(13,15,22,25)$. These cells are also capable of producing a "progression" factor. In 1982, Bitterman and colleagues (26) described a polypeptide with "progression" activity released from activated alveolar macrophages. This mediator, termed "alveolar macrophage-derived growth factor" (or AMDGF) had no "competence" activity, but in serum-free conditions was capable of stimulating PDGF or fibronectin-primed fibroblasts to move through $G_{1}$ and synthesize DNA within $8 \mathrm{~h}$ (25). Furthermore, in fibrotic lung disorders such as IPF and asbestosis, AMDGF was spontaneously released, but was not detectable in supernatants of normal resting alveolar macrophages $(27,28)$. At the time of its discovery, evaluation of AMDGF suggested it was different from all other known growth factors (26). Specifically, in regards to the "progression" class of fibroblast growth factors, its apparent molecular mass insured it was not insulin, insulinlike growth factor-I (IGF-I, “somatomedin C") or insulin-like growth factor-II (IGF-II) (29).

Attempts to further characterize AMDGF have been hampered by the difficulty in obtaining sufficient numbers of alveolar macrophages necessary to purify the protein. However, several recent observations have led us to reevaluate the possibility that AMDGF may be a member of the IGF-I family. First, "tissue-type" forms of IGF-I have been recently described. Clemmons et al. $(30,31)$ have found a fibroblast type of IGF-I with a molecular mass of $21.5 \mathrm{kD}$, and Smith et al. (32) have characterized a Sertoli cell-produced type of IGF-I with a molecular mass of $25 \mathrm{kD}$. Both of these tissue IGF-Ilike molecules have molecular masses approximately threefold greater than the plasma form of IGF-I and in the same range as AMDGF. Second, Rotwein and colleagues $(33,34)$ have demonstrated that the IGF-I gene can be expressed in a variety of ways, utilizing alternative splicing to produce different IGF-I mRNA transcripts. Finally, Han et al. (35), using in situ hybridization, have demonstrated that most fetal tissues express the IGF-I gene, including the interstitium of the lung, one site where alveolar macrophages reside.

In this context, the present study was directed toward evaluating the hypothesis that alveolar macrophages produce a progression-type growth factor for fibroblasts with properties that place it as a member of the IGF-I family. The data demonstrate that this is the case, and suggest that this mediator, pre- 
viously described as "alveolar macrophage-derived growth factor," is an IGF-I-type molecule.

\section{Methods}

Collection of supernatants of activated alveolar macrophages. With the knowledge that a progression-type growth factor for fibroblasts (previously termed AMDGF) is released spontaneously by alveolar macrophages from patients with interstitial lung disease $(10,27,28)$ or by normal alveolar macrophages activated in vitro (26), supernatants were collected from alveolar macrophages from two general sources. First, alveolar macrophages were obtained by bronchoalveolar lavage from individuals with the interstitial lung disorders idiopathic pulmonary fibrosis, sarcoidosis, silicosis, or asbestosis $(27,28)$. Secondly, alveolar macrophages were obtained by whole-lung lavage of lungs removed at autopsy from deceased individuals within $12 \mathrm{~h}$ of death from trauma. Approximately 1.5 liters of saline was infused through an endotracheal tube with recovery of $100-600 \times 10^{6}$ bronchoalveolar cells per lung. After adherence to a $15-\mathrm{cm}$ plastic dish for $1 \mathrm{~h}$, the cells were extensively washed to remove nonadherent cells (lymphocytes, bronchial epithelial cells). In all cases, the resulting cell populations were $>90 \%$ alveolar macrophages with alveolar macrophage viability $>90 \%$ by exclusion of trypan blue dye.

Alveolar macrophages from all sources were cultured $\left(37^{\circ} \mathrm{C}\right)$ in tissue culture dishes ( $15 \mathrm{~cm}$, Falcon Labware, Oxnard, CA), in Dulbecco's modified Eagle's medium (DME) supplemented with $2 \mathrm{mM}$ glutamine and $10 \mu \mathrm{g} / \mathrm{ml}$ gentamicin at a concentration of $10^{6} \mathrm{cells} / \mathrm{ml}$. Alveolar macrophages from individuals with interstitial lung disease were cultured without additional stimulation in as much as it is known that these cells spontaneously release a progression-type growth factor $(10,27,28)$. Macrophages from deceased individuals were stimulated with autoclaved intermediate-length chrysotile asbestos (National Institute for Environmental Health Sciences) at a concentration of 100 $\mu \mathrm{g} / \mathrm{ml}$, a stimulus known to markedly activate alveolar macrophages to release the progression-type mediator (36). After $1 \mathrm{~h}$, nonadherent cells were removed and discarded. The incubations were continued with supernatants harvested at 4-h intervals until $16 \mathrm{~h}$. Since the purpose was to collect as much of the progression-type growth factor as possible, all supernatants were pooled.

Quantification of the progression-type growth factor activity. The progression-type growth factor activity released by the activated alveolar macrophages was quantified using a complementation assay as previously described in detail for AMDGF (26). After incubation of column fractions with noncycling fibroblasts, cells were detached with 0.25\% trypsin and counted in a cell counter (Coulter Electronics, Inc., Hialeah, FL). The units of progression-type growth activity in the alveolar macrophage supernatants or in partially purified material (see below) were based on dilution analysis and compared to medium alone as previously described for AMDGF (26). After stimulation with an inorganic particulate, chrysotile asbestos, release of growth factor activity (in amounts per $10^{6}$ cells per hour) among all macrophage populations used in the present study was similar to that obtained by cells from normal volunteers stimulated in a similar fashion (26).

Enzyme-linked immunoassay for IGF-I. Column chromatography fractions during the purification procedures (see below) were assessed for molecules with antigenic cross-reactivity with IGF-I using an enzyme-linked immunosorbent assay (ELISA) (37) with a polyclonal antibody to human serum IGF-I, donated to National Hormone and Pituitary Agency, Baltimore, MD, by L. Underwood and J. J. van Wyk, University of North Carolina (38), using conventional methods with recombinant IGF-I (rIGF-I, Amgen, Thousand Oaks, CA) as a standard. Thus, values reported for this assay are "rIGF-I equivalents." Briefly, sample aliquots and rIGF-I standard were serially diluted, incubated with the polyclonal IGF-I antibody, and transferred to rIGFI-coated $(50 \mathrm{ng} / \mathrm{ml})$ 96-well flat-bottom plates for $30 \mathrm{~min}$. After washing, the plates were incubated with a peroxidase-linked anti-rabbit immunoglobulin $\mathrm{G}$ followed by $\boldsymbol{O}$-phenylenediamine and hydrogen peroxide, with the color change read spectrophotometrically.

Partial purification of the alveolar macrophage progression growth factor activity for fibroblasts. As previously described for AMDGF, the alveolar macrophage progression-type growth activity was partially purified by ion-exchange chromatography followed by size-exclusion chromatography (26). Supernatants from the cultured macrophages were pooled and dialyzed ( $20 \mathrm{vol}$, three buffer changes) into "starting buffer" ( $20 \mathrm{mM} \mathrm{NaCl}, 20 \mathrm{mM}$ Tris- $\mathrm{HCl}, \mathrm{pH} \mathrm{8.0)}$ ) for the ion-exchange column (DEAE cellulose, DE-52, Whatman, Inc., Clifton, NJ). Typically, the initial column was used to evaluate 1 liter of conditioned media generated from $5 \times 10^{8}$ alveolar macrophages from 10 individuals. The DEAE column was eluted with a salt gradient (20-300 mM $\mathrm{NaCl}$ in the starting buffer). Column fractions were assessed for progression-type fibroblast growth activity and for antigenic cross-reactivity for IGF-I (by ELISA) as described above. Fractions with the growth activity were pooled and chromatographed on a gel filtration column (G-100, Pharmacia Fine Chemicals, Piscataway, NJ), equilibrated, and eluted in phosphate-buffered saline, pH 7.4. The G-100 column was calibrated with molecular mass standards (Bio-Rad Laboratories, Richmond, CA). The fractions were assessed as described above and the fractions demonstrating fibroblast growth activity were pooled, dialyzed against $\mathrm{H}_{2} \mathrm{O}$, and stored at $-70^{\circ} \mathrm{C}$ in lyophilized $1-\mathrm{ml}$ aliquots. Protein concentrations in starting material and pooled column fractions were determined with a colorimetric assay (Bio-Rad Laboratories) with bovine serum albumin as a standard.

To confirm the presence of an IGF-I-like molecule in the column fractions and demonstrate that the macrophage IGF-I-like molecule "tracked" with the macrophage progression-type growth activity, pooled column fractions from the DEAE and gel-filtration columns were assayed for progression-type growth activity, and the samples (in a blinded fashion) were quantified for IGF-I using a radioimmunoassay $(30,31,38)$ (IGF-I radioimmunoassay kindly performed by $D$. Clemmons, University of North Carolina).

Comparison of the apparent molecular mass of the alveolar macrophage IGF-I-type molecule and recombinant IGF-I. The apparent molecular mass of the macrophage IGF-I-type molecule was compared to that of rIGF-I by analytical Superose-12 gel filtration chromatography. The pooled peak fractions from the DEAE column were chromatographed using a fast protein liquid chromatography (FPLC) system in phosphate-buffered saline, pH 7.4. In addition, the molecular mass was determined under acidic conditions using $1 \mathrm{M}$ acetic acid and a P-100 column. Fractions were assessed for progression-type growth activity (see below) and antigenic cross-reactivity with IGF-I by ELISA. For comparison, rIGF-I was chromatographed on the same columns and assessed in a similar fashion. Standard molecular mass markers were used to calibrate the columns (Bio-Rad Laboratories).

Serum-free complementation assay. Serum-free complementation assays were performed with diploid human fetal lung fibroblasts (HFL-1; American Tissue Culture Collection CCL 153). Cells were removed from a tissue culture dish by brief incubation in trypsin ( 5 $\left.\mathrm{min}, 37^{\circ} \mathrm{C}\right)$, plated at $6 \times 10^{4} \mathrm{cells} / \mathrm{ml}(0.5 \mathrm{ml} /$ well $)$, and cultured in DME supplemented with $10 \%$ calf serum (M.A. Bioproducts, Walkersville, MD). On day 8 , the medium was aspirated and the cells were washed two times with complementation medium (DME supplemented with $1 \mathrm{mg} / \mathrm{ml}$ bovine serum albumin [Sigma Chemical Co., St.

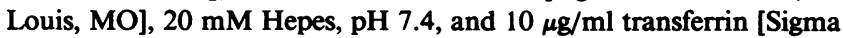
Chemical Co.]). On day 9, growth factors (see below) were added and the culture was continued for $18 \mathrm{~h}$. For the last $2 \mathrm{~h}$ of culture, $\left[{ }^{3} \mathrm{H}\right]$ thymidine $(2 \mu \mathrm{Ci} / \mathrm{ml} ; 2 \mathrm{Ci} / \mathrm{mmol}$; Amersham Corp., Arlington Heights, IL) was added; this period of labeling was chosen because under the conditions used, HFL-1 fibroblasts demonstrated maximal DNA synthesis $16-18 \mathrm{~h}$ after growth factor addition. After incubation, the medium was aspirated, trypsin was added $\left(10 \mathrm{~min}, 37^{\circ} \mathrm{C}\right)$, and the cells were pipetted onto filter paper strips (GB004, Schleicher \& Schuell, Inc., Keene, NH), dried, washed in cold $10 \%$ trichloroacetic acid for $\mathbf{1 ~ h}$, washed twice in 5\% trichloroacetic acid for $30 \mathrm{~min}$ each, 
rinsed in ethanol followed by ether, dried, and counted in a scintillation counter.

PDGF (Collaborative Research, Inc., Waltham, MA) and recombinant IGF-I (rIGF-I, Amgen) were used as defined "competence" and "progression" factors, respectively. All complementation assays for the macrophage progression-type activity were performed with $4 \mathrm{ng} / \mathrm{ml}$ PDGF and the macrophage supernatant (or column fractions), and al positive controls for the assay were performed with $4 \mathrm{ng} / \mathrm{ml}$ PDGF and $10 \mathrm{ng} / \mathrm{ml} \mathrm{rIGF}-\mathrm{I}$. To further demonstrate that the alveolar macrophage progression-type growth activity is a member of the IGF-I family, growth activity was also evaluated in the presence of increasing concentrations of a monoclonal antibody to human serum IGF-I, anti-somatomedin-C 1.2, a gift of J. J. Van Wyk (39), University of North Carolina, using an irrelevant monoclonal antibody of the same class ( $\mathrm{IgG}_{1}$ kappa) as a control. All experiments were carried out in triplicate, with duplicate values for each point in each assay.

Competitive binding assay of the alveolar macrophage IGF-I-type mediator for the IGF-I receptor. To determine if the alveolar macrophage IGF-I-type mediator would compete with rIGF-I for its receptor, a competitive binding assay was utilized based on the IGF-I radioreceptor assay described by Rosenfeld et al. $(40,41)$. HFL-1 fibroblasts were cultured $\left(6 \times 10^{4}\right.$ cells $\left./ \mathrm{ml}\right)$ in DME supplemented with $10 \%$ calf serum on $35-\mathrm{mm}$ Falcon tissue culture dishes for $7 \mathrm{~d}$ at $37^{\circ} \mathrm{C}$. The medium was aspirated, and monolayers were washed twice with 100 $\mathrm{mM}$ Hepes, pH 7.4, 0.5\% bovine serum albumin, $120 \mathrm{mM} \mathrm{NaCl}, 1.2$ $\mathrm{mM} \mathrm{MgSO}, 5 \mathrm{mM} \mathrm{KCl}, 15 \mathrm{mM}$ sodium acetate, and $10 \mathrm{mM}$ dextrose. Monolayers were then incubated $\left(2 \mathrm{~h}, 4^{\circ} \mathrm{C}\right)$ on a gentle rocker with ${ }^{125}$ I-rIGF-I ( $10^{5} \mathrm{dpm}$; labeled by the chloramine-T method [42]) plus various concentrations of unlabeled macrophage IGF-I-type mediator in a final volume of $2 \mathrm{ml}$ of buffer. At the end of the incubation, the buffer was aspirated, and the monolayers gently washed five times with $1 \mathrm{ml}$ Hanks' balanced salt solution $\left(4^{\circ} \mathrm{C}\right)$. The fibroblast monolayers were then solubilized $(1.5 \mathrm{ml}$ of $1 \mathrm{M} \mathrm{NaOH})$ and transferred to a polypropylene tube for counting in a gamma counter. Nonspecific binding was defined as the amount of added ${ }^{125}$ I-rIGF-I that remained bound in the presence of $250 \mathrm{ng} / \mathrm{ml}$ of unlabeled rIGF-I. As a positive control for comparison to the macrophage mediator, increasing amounts of rIGF-I were evaluated in the same manner. As negative controls fibroblast growth factor (Collaborative Research), insulin-like growth factor II (multiplication stimulating activity, MSA III-2, purified according to Greenstein et al. [43], a gift of S. Peter Nissley, National Cancer Institute) and insulin (Collaborative Research) were evaluated in the same assay. To rule out the possibility that the displacement of the labeled rIGF-I from the IGF-I receptor was not due to the presence of an IGF-I binding protein, macrophage supernatants were evaluated for the presence of IGF-I binding proteins using an activated charcoal assay (performed courtesy of $M$. Rechler, National Institute of Digestive Diseases and Kidney [29, 44]).

Alveolar macrophage IGF-I-type mediator-induced phosphorylation of an artificial tyrosine-containing substrate by the IGF-I receptor. To demonstrate that binding of the alveolar macrophage IGF-I-type molecule to the IGF-I receptor activated the receptor in a fashion similar to that of IGF-I, evaluation of phosphorylation of a tyrosinecontaining substrate by the receptor was shown using minor modifications of the method of Sasaki et al. (45). Fibroblasts were grown to confluence in DME supplemented with $10 \%$ calf serum, washed twice in serum-free medium, and cultured for an additional $24 \mathrm{~h}$ at $37^{\circ} \mathrm{C}$ in serum-free medium. Fibroblast monolayers were removed and washed with $0.25 \mathrm{M}$ sucrose, $50 \mathrm{mM}$ Hepes, $\mathrm{pH}$ 7.6, $2 \mathrm{mM}$ phenylmethylsulfonyl fluoride (PMSF), and 1 trypsin-inhibitor unit (TIU; $6.6 \mu \mathrm{g} / \mathrm{ml}$ ) of aprotinin. The fibroblasts were disrupted by sonication for $10 \mathrm{~min}$, centrifuged $600 \mathrm{~g}$ for $10 \mathrm{~min}$, and the supernatant was centrifuged $12,000 \mathrm{~g}$ for $30 \mathrm{~min}$ to remove cellular debris and organelles. The supernatant was centrifuged $100,000 \mathrm{~g}$ for $60 \mathrm{~min}$, and the pellet resuspended in $50 \mathrm{mM}$ Hepes, pH 7.6, $2 \mathrm{mM}$ PMSF, $1 \mathrm{TIU} / \mathrm{ml}$ aprotinin, $10 \mathrm{mM} \mathrm{MgSO}_{4}, 1 \%$ Triton X-100, stirred $30 \mathrm{~min}$ at $4^{\circ} \mathrm{C}$, and centrifuged $100,000 \mathrm{~g}$ for $60 \mathrm{~min}$. The supernatant was applied to a 5-ml column of wheat-germ agglutinin agarose (Pharmacia Fine Chemicals) and eluted with $0.3 \mathrm{M} \mathrm{N}$-acetylglucosamine (Sigma Chemical Co.), 50 $\mathrm{mM}$ Hepes, $\mathrm{pH} 7.6$, and $1 \%$ Triton X-100. Protein concentration was determined using the Bio-Rad colorimetric assay. To ensure that the receptor preparations were functional, autophosphorylation of the type I IGF-I receptor was assessed according to the method of Sasaki et al. (45). An IGF-I dose-dependent increase of the labeled $98-\mathrm{kD}$ band representing the $\beta$-subunit of the type I IGF receptor was demonstrated by sodium dodecyl sulfate (SDS) polyacrylamide gel electrophoresis and autoradiography. The purified receptor preparations were stored at $-70^{\circ} \mathrm{C}$ in $0.5-\mathrm{ml}$ aliquots until needed.

To demonstrate that the alveolar macrophage IGF-I-type molecule could activate the tyrosine kinase within the IGF-I receptor in a fashion similar to rIGF-I, the partially purified alveolar macrophage mediator was added to the purified receptor preparations in the presence of ${ }^{32}$ P-labeled $\gamma$-ATP and a tyrosine-containing artificial substrate (45). Receptor membranes ( $50 \mu \mathrm{l}, 7.5 \mu \mathrm{g}$ of protein) were incubated with

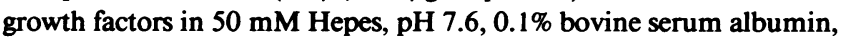
$0.1 \%$ Triton X-100, $10 \mathrm{mM}$ magnesium acetate (Sigma Chemical Co.) and $50 \mu \mathrm{M}$ ATP (Sigma Chemical Co.) for $10 \mathrm{~min}, 22^{\circ} \mathrm{C}$, in a total volume of $100 \mu$ l. Phosphorylation was started by adding $\left[\gamma-{ }^{32} \mathrm{P}\right] \mathrm{ATP}$ $\left(6 \times 10^{6} \mathrm{dpm} /\right.$ reaction mixture; $6,000 \mathrm{Ci} / \mathrm{mmol}$, Amersham Corp. $), 1$ mM CTP (to decrease hydrolysis of ATP by ATPases), and $2.2 \mathrm{mg} / \mathrm{ml}$ of the exogenous substrate poly(Glu,Tyr) 4:1 (Sigma Chemical Co.) for $20 \mathrm{~min}, 22^{\circ} \mathrm{C}$. The reaction was terminated by spotting $125-\mu \mathrm{l}$ samples onto Whatman $3 \mathrm{MM}$ filter paper and washing in 10\% cold trichloroacetic acid. The filter papers were extensively washed in 5\% trichloroacetic acid, rinsed in ethanol, and dried, and ${ }^{32} \mathrm{P}$-incorporation into the artificial substrate was determined by liquid scintillation counting. Actual substrate phosphorylation was determined by subtracting ${ }^{32} \mathrm{P}$ incorporation in the absence of the artificial substrate.

Detection of IGF-I MRNA transcripts in human alveolar macro phages. Alveolar macrophages were recovered from a normal individual and an individual with asbestosis utilizing bronchoalveolar lavage, and normal human blood monocytes were separated over Ficoll-Hypaque and purified by adherence to plastic for $1 \mathrm{~h}, 37^{\circ} \mathrm{C}$ followed by five washes with PBS. Normal human liver was obtained at open biopsy and frozen at $-120^{\circ} \mathrm{C}$. Cellular RNA was extracted with $5.2 \mathrm{M}$ guanidine isothiocyanate and purified through a $\mathrm{CsCl}$ cushion centrifugation (35,000 rpm, 12 h). An IGF-IA cDNA (a gift of P. Rotwein, St. Louis, MO) in pGEM1 was used to construct an antisense riboprobe utilizing 380 bp (exons I-II-III of the original clone cut at EcoRI site) and labeled with [ $\left.{ }^{32} \mathrm{P}\right]$ UTP. Solution hybridization was performed according to Zinn et al. (46). Briefly, $10 \mu \mathrm{g}$ of total RNA and the antisense RNA probes $\left(10^{6} \mathrm{dpm} /\right.$ tube) were hybridized in $0.6 \mathrm{M} \mathrm{NaCl}$, 12.5 mM EDTA, pH 7.0, 25 mM Tris- $\mathrm{HCl}$ pH 7.5, 0.25\% sodium dodecyl sulfate, $25 \mathrm{mM}$ dithiothreitol, and $25 \%$ formamide $\left(55^{\circ} \mathrm{C}, 16\right.$ h). The mixture was treated with RNase A (10 ng) and RNase T1 (5.6 ng; Sigma Chemical Co.) and the protected RNA/RNA hybrids extracted with phenol/chloroform and precipitated with ethanol. DNA size markers (\$X 174 RF/HaeIII, Bethesda Research Laboratories, Gaithersburg, MD) were labeled with $\left[\gamma-{ }^{32} \mathrm{P}\right]$ ATP $(5,400 \mathrm{Ci} / \mathrm{mmol}$, Amersham Corp.) by $5^{\prime}$ end-terminus labeling. The dried RNA pellets or markers were dissolved in $5 \mu \mathrm{l}$ of loading buffer $(0.1 \%$ xylene cyanol, $0.1 \%$ bromophenol blue, $10 \mathrm{mM}$ EDTA, and $90 \%$ formamide), heated to $65^{\circ} \mathrm{C}$ for $5 \mathrm{~min}$, and electrophoresed on $8 \%$ polyacrylamide gels in urea in $1 \times$ TBE buffer ( $50 \mathrm{mM}$ Tris, $50 \mathrm{mM}$ boric acid, $1 \mathrm{mM} \mathrm{Na}_{2}$ EDTA) at $1,500 \mathrm{~V}, 4 \mathrm{~h}$. The gel was dried $\left(80^{\circ} \mathrm{C}, 1 \mathrm{~h}\right)$, and autoradiograms were performed with an intensifying screen for $3 \mathrm{~d}$ at $-70^{\circ} \mathrm{C}$.

Statistical evaluation. All assays were performed in triplicate with values presented as mean \pm standard error of the mean. Paired data were evaluated using the two-tailed Student's $t$ test.

\section{Results}

As previously described (26-28), supernatants of activated alveolar macrophages contain a mediator with progression-type 
growth activity for fibroblasts that elutes from DEAE-cellulose at $270 \mathrm{mM} \mathrm{NaCl}$ (Fig. 1). Importantly, assessment of the same fractions of the DEAE column with an IGF-I specific ELISA demonstrated that $(a)$ supernatants of activated alveolar macrophages contain a mediator with antigenic determinants that are detected with an anti-IGF-I antibody, and $(b)$ the macrophage IGF-I type mediator co-eluted on DEAE with the progression-type growth activity.

When the peak of progression-type growth factor activity was pooled and rechromatographed by G-100 size-exclusion chromatography, two facts became apparent. First, the progression-type growth factor activity and the macrophage IGF-I-type molecule tracked together (Figure 1). In this regard, the growth activity eluting from the ion-exchange column was further purified sixfold by the size column, but so was the IGF-I-type mediator, i.e., after the DEAE step, the ratio of the progression activity to IGF-I was 159 activity units/ng whereas after the size chromatography step it was 142 (Table I). These observations are consistent with the concept that a significant proportion, if not all, of the alveolar macrophage progression-type growth activity was due to an IGF-Itype molecule released by the macrophage. Consistent with this concept, addition of an anti-IGF-I monoclonal antibody in a dose-response manner to the fibroblast cultures significantly reduced fibroblast DNA synthesis induced by the combination of PDGF and the alveolar macrophage IGF-I in serum-free conditions (Fig. 2). A nonspecific mouse monoclonal antibody ( $\operatorname{IgG}_{1}$ kappa, the same class as the anti-IGF-I monoclonal antibody) had no effect on the functional activity of the macrophage IGF-I-type molecule. As observed in the present study with the alveolar macrophage IGF-I-type mediator and by Clemmons and Van Wyk (47) with serum IGF-I, the anti-IGF-I monoclonal also suppressed the effect of PDGF plus recombinant IGF-I in a dose-dependent fashion (not shown).

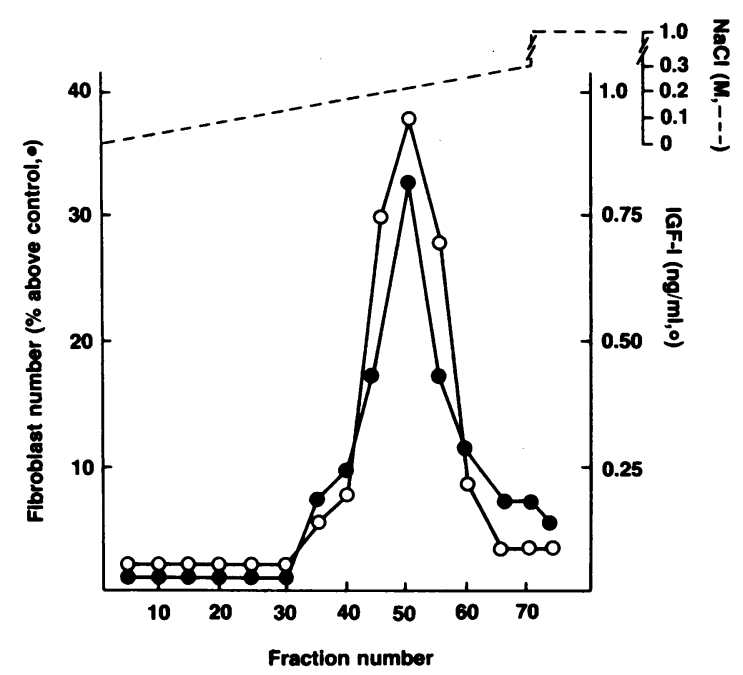

Figure 1. DEAE-cellulose chromatography of supernatants of alveolar macrophages. The column was eluted with a $\mathrm{NaCl}$ gradient and the fractions were assayed for growth factor activity as described in Methods. Shown is the mean of duplicate samples for progressiontype fibroblast growth factor activity expressed as percent increase in fibroblast number over control $(\bullet)$ and the amount IGF-I quantified ( $\mathrm{ng} / \mathrm{ml}$ ) by an enzyme-linked immunoassay using a polyclonal antisomatomedin C antibody (O).
Interestingly, despite the fact that it was detected by an anti-IGF-I antibody, the alveolar macrophage IGF-I-type mediator actually had an apparent molecular mass higher than serum IGF-I itself (Fig. 3). When chromatographed on Superose-12, rIGF-I had an apparent molecular mass of $8 \mathrm{kD}$, consistent with its known composition of 70 amino acids and molecular mass of $7.6 \mathrm{kD}$. Consistent with this observation, when the alveolar macrophage IGF-I-type mediator was chromatographed in acid conditions using $1 \mathrm{M}$ acetic acid for the buffer, the observed molecular mass was also $26 \mathrm{kD}$, suggesting the alveolar macrophage IGF-I-type molecule was not associated with another protein (data not shown). In addition, evaluation of macrophage supernatants for the presence of an IGF-I binding protein were negative (not shown).

Further evidence that the alveolar macrophage mediator detected by the polyclonal and monoclonal anti-IGF-I antibodies was a member of the IGF-I family was provided by the observation that the macrophage IGF-I-type mediator competed with IGF-I for its receptor on fibroblasts (Fig. 4). In this regard, $50 \%$ competitive binding for the receptor occurred with the macrophage IGF-I molecule at $8 \mathrm{ng} / \mathrm{ml}$ (ELISA units), a somewhat lower value than that with rIGF-I (23 $\mathrm{ng} / \mathrm{ml}$ ). In contrast, fibroblast growth factor, a mediator unrelated to the IGF-I family, demonstrated no competition for the IGF-I receptor. As described by others (29), insulin-like growth factor II (IGF-II) exhibited modest competition for the receptor, and insulin displaced the ${ }^{125}$ I-rIGF-I only at doses at least two orders of magnitude greater. Interestingly, the slope of the competitive binding assay for the alveolar macrophage IGF-I was shifted leftward of rIGF-I consistent with a greater binding affinity for the receptor on HFL-I fibroblasts. However, while it is conceivable that this observation represents the macrophage IGF-I-type molecule actually having a higher affinity for the IGF-I receptor than rIGF, it must be kept in mind that the apparent molecular mass of the macrophage IGF-I-type molecule is approximately threefold that of IGF-I (Fig. 3), but that the estimates of the amounts of the macrophage IGF-Itype molecule added to the radioreceptor assay were based on a rIGF-I standard. In this regard, it is unknown how many epitopes the polyclonal antibody detects, or whether it is the same or different number on the macrophage-type IGF-I mediator and rIGF-I. It is unlikely, however, that IGF-I binding proteins produced by the macrophages were complicating the analysis, since no IGF-I binding proteins were detected in any of the alveolar macrophage samples.

Not only did the macrophage IGF-I-type mediator compete with rIGF-I for its receptor, but, like rIGF-I, interaction of the macrophage IGF-I-type mediator with purified IGF-I receptor activated the receptor to phosphorylate an artificial tyrosine substrate. In this context, like rIGF-I, the macrophage IGF-I was able to stimulate the tyrosine kinase activity within the IGF-I receptor to phosphorylate the exogenous substrate poly(Glu,Tyr) 4:1 in a dose-dependent manner (Fig. 5). Importantly, with the same caveats concerning the amounts of macrophage IGF-I given for the radioreceptor assay (see above), the macrophage IGF-I dose-response curve closely paralleled rIGF-I. In contrast, fibroblast growth factor demonstrated no phosphorylation of the substrate. Insulin was also able to phosphorylate the receptor and increase phosphorylation of the substrate, but at concentrations two orders of magnitude greater than IGF-I. 
Table I. Co-Purification of Alveolar Macrophage Progression-Type Growth Activity for Fibroblasts and a Molecule with Antigenic Cross-Reactivity with Insulin-like Growth Factor I

\begin{tabular}{|c|c|c|c|c|c|c|}
\hline Purification step & $\begin{array}{l}\text { Total growth } \\
\text { activity }\end{array}$ & Protein & $\begin{array}{l}\text { Specific growth } \\
\text { activity }\end{array}$ & $\begin{array}{l}\text { Purification } \\
\text { ratio }\end{array}$ & IGF-I & Growth activity \\
\hline & $\times 10^{3}$ units $^{*}$ & $\mu g$ & units/ug protein & & $n g^{*}$ & units/IGF-I (ng) \\
\hline Macrophage starting supernatant & 128.0 & 4600 & 27.8 & 1.0 & Not detectable & - \\
\hline DEAE cellulose & 17.9 & 190 & 94.4 & 3.4 & 113 & 159 \\
\hline Gel filtration & 5.2 & 9.3 & 564.0 & 20.3 & 37 & 142 \\
\hline
\end{tabular}

* Units are defined by dilution analysis (see reference 26 ). ${ }^{\ddagger}$ Quantified by radioimmunoassay using an IGF-I standard purified from serum $(30,31,38)$; assays performed by D. Clemmons, University of North Carolina.

Consistent with the observations at the protein level, fresh alveolar macrophages expressed transcripts with mRNA sequences complementary to exons I-III of the IGF-I gene (Fig. 6). Using a ${ }^{32} \mathrm{P}$-labeled riboprobe constructed of 380 base pairs of IGF-I exons I, II, and III encompassing the region coding for serum IGF-I, solution hybridization demonstrated alveolar macrophages from a normal individual and an individual with asbestosis (Fig. $6 \mathrm{~B}$, lanes 2 and 3), but not blood monocytes (lane 4), contained mRNA transcripts complementary to the IGF-I gene, in a fashion similar to that of human liver (lane 1).

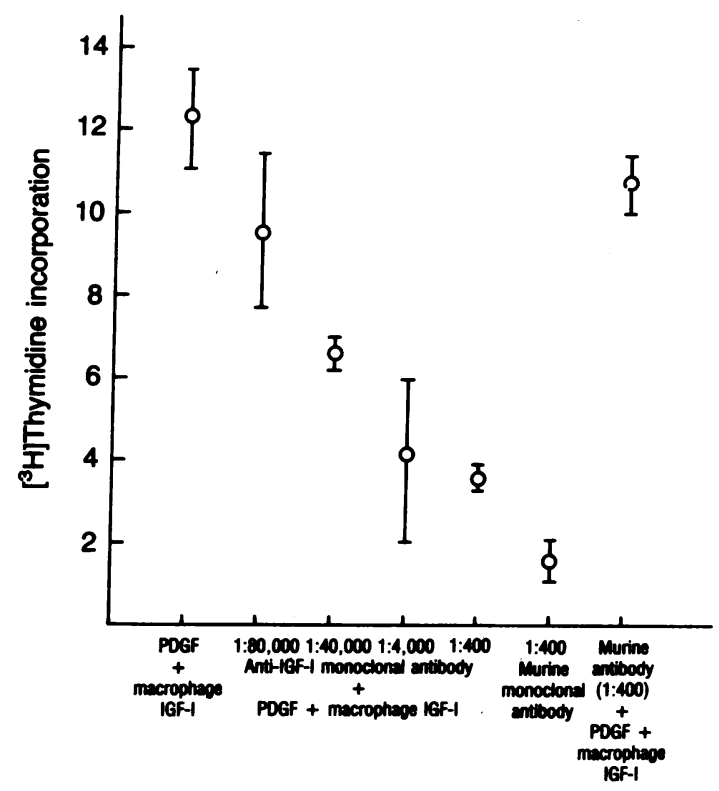

Figure 2. Effects of the macrophage IGF-I plus PDGF on DNA synthesis in fibroblasts in the presence of increasing concentration of anti-IGF-I monoclonal antibody. PDGF $(4 \mathrm{ng} / \mathrm{ml})$, macrophage IFG-I $(<1 \mathrm{ng} / \mathrm{ml})$, and increasing concentrations $(0,1: 80,000$; $1: 40,000 ; 1: 4,000$; and $1: 400$ ) of the anti-somatomedin-C 1.2 monoclonal antibody (see Russell et al. [39] for details concerning the antibody) were evaluated in the serum-free complementation growth assay as described in the text. Baseline $\left[{ }^{3} \mathrm{H}\right]$ thymidine incorporation in the presence of no added growth factors was subtracted from all data. $\left[{ }^{3} \mathrm{H}\right]$ thymidine incorporation is presented as dpm/4 $\times 10^{5} \mathrm{fi}-$ broblasts per $2 \mathrm{~h}$. An irrelevant mouse monoclonal antibody $\left(\mathrm{IgG}_{1}\right.$ kappa same as the anti-IGF-I) at a concentration of 1:400 had no effect alone or in the presence of PDGF plus the macrophage IGF-I.

\section{Discussion}

When activated, human alveolar macrophages release a progression-type growth factor for fibroblasts that acts late in $\mathbf{G}_{1}$ of the cell cycle to signal "competent" fibroblasts to proliferate

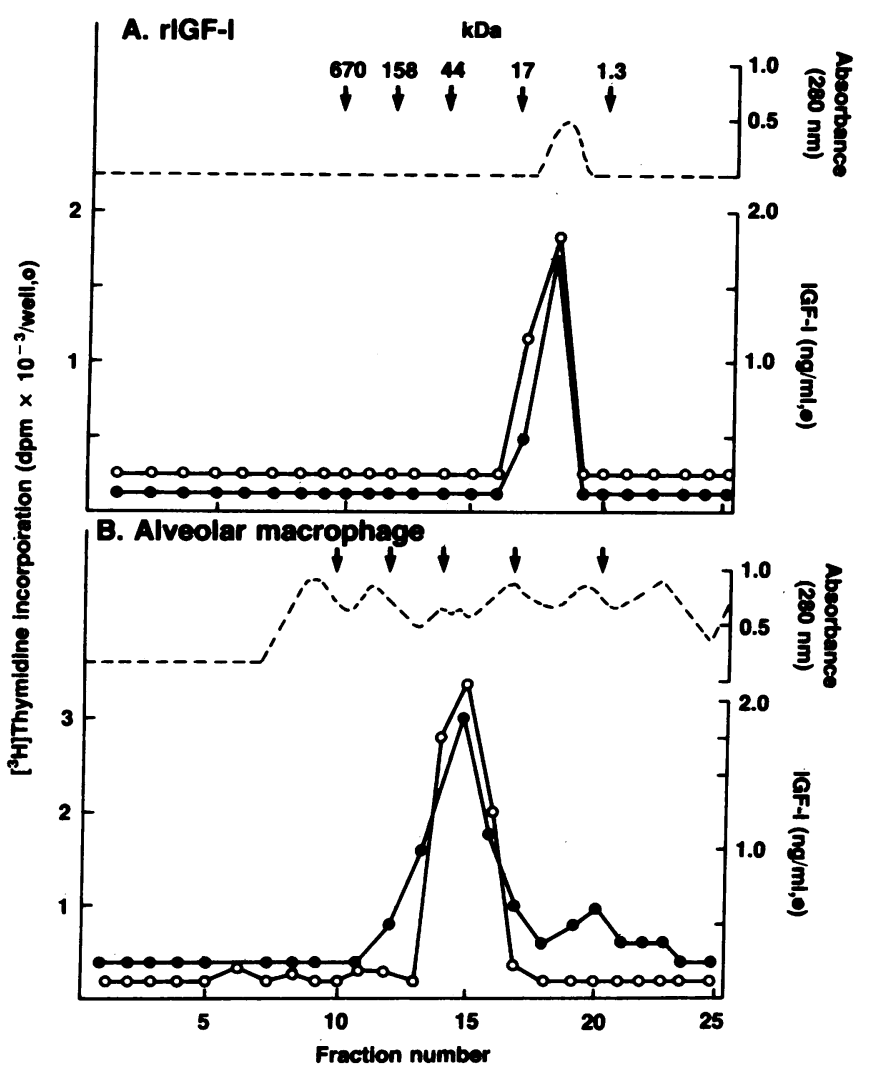

Figure 3. Comparison of the apparent molecular mass of the alveolar macrophage IGF-I-like mediator to that of rIGF-I. Recombinant IGF-I and the DEAE-cellulose purified alveolar macrophage IGF-Itype mediator were chromatographed by Superose- 12 gel filtration and the fractions were evaluated for progression-type growth activity for fibroblasts and for IGF-I by ELISA. $(A)$ Recombinant IGF-I. ( $B)$ Alveolar macrophage IGF-I-like mediator. For $A$ and $B$, shown are absorbance at $280 \mathrm{~nm}(---)$, and mean of duplicate samples for progression-type growth activity (O), and IGF-I as determined by ELISA (๑). The $\mathrm{ED}_{50}$ relative to the positive control for rIGF-I is 4.4 $\mathrm{ng} / \mathrm{ml}$ and for the alveolar macrophage IGF-I-type mediator is $\mathbf{1 . 2}$ $\mathrm{ng} / \mathrm{ml}$. 


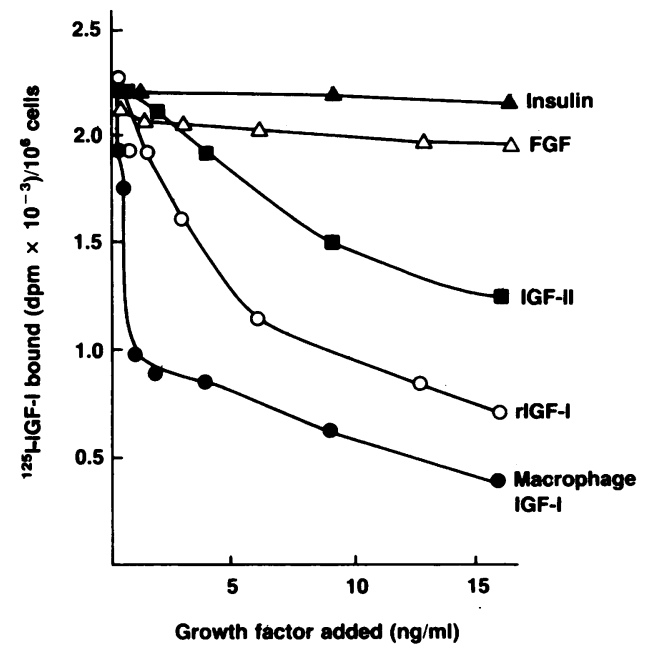

Figure 4. Competition of the alveolar macrophage IGF-I-like mediator and rIGF-I for the IGF-I receptor. The alveolar macrophage IGF-I-like mediator partially purified by DEAE chromatography was incubated $\left(2 \mathrm{~h}\right.$ at $\left.4^{\circ} \mathrm{C}\right)$ with HFL-I fibroblasts with ${ }^{125} \mathrm{I}$-IGF-I. The cells were washed and solubilized and the bound ${ }^{125}$ I-IGF-I was quantified. The amount of the alveolar macrophage IGF-I-like mediator added was determined by ELISA using a rIGF-I standard. Shown is mean of duplicate samples for the specific binding (nonspecific binding subtracted) of unlabeled rIGF-I (O), alveolar macrophage IGF-I-type mediator (๑), and as controls, fibroblast growth factor $(\Delta)$, IGF-II ( $\bullet)$, and insulin ( $\mathbf{\Delta})$.

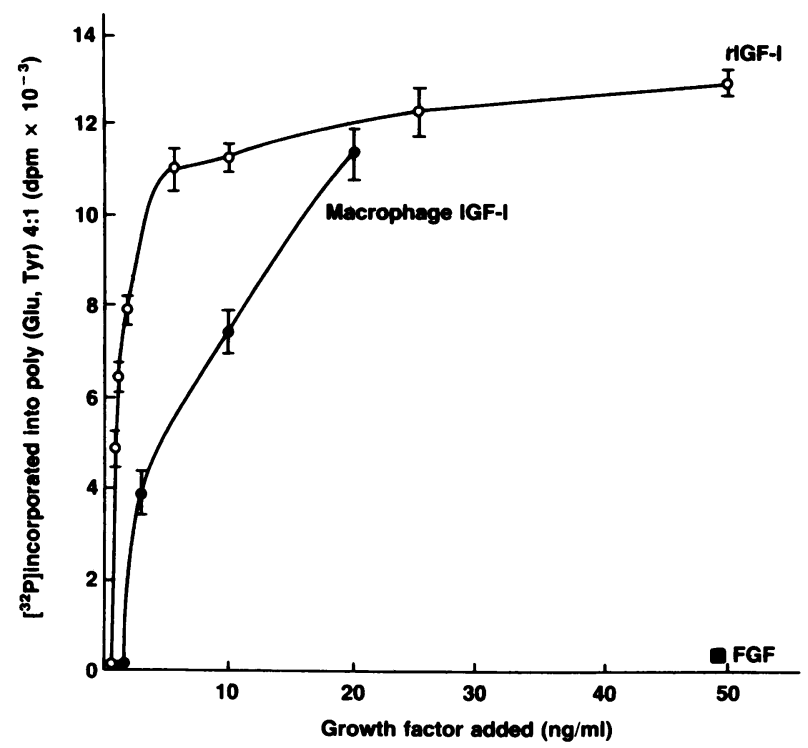

Figure 5. Effect of the alveolar macrophage IGF-I-like mediator on fibroblast IGF-I receptor-induced phosphorylation of poly(Glu,Tyr) 4:1 substrate. IGF-I receptors purified from confluent human fetal lung fibroblasts were incubated $\left(20 \mathrm{~min}\right.$ at $\left.22^{\circ} \mathrm{C}\right)$ with poly(Glu,Tyr) $4: 1$ and $\left[\gamma-{ }^{32} \mathrm{P}\right] \mathrm{ATP}$ in the presence of rIGF-I (O), alveolar macrophage IGF-I-type mediator (•), and, as a control, fibroblast growth factor ( () . The amounts of the alveolar macrophage IGF-I-type mediator were determined by ELISA using a rIGF-I standard. After incubation, the reaction mixtures were precipitated, washed, and counted. Background (no substrate) was substracted from each value.
A

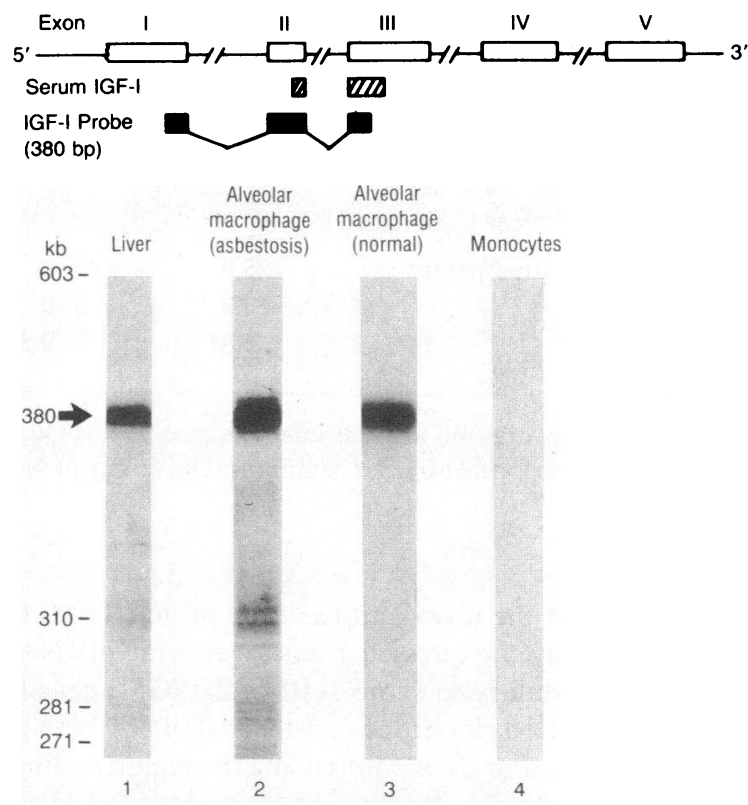

Figure 6. Expression of IGF-I gene mRNA transcripts in alveolar macrophages. $(A)$ The IGF-I gene has five coding exons. The 70amino acid serum IGF-1 is derived from coding sequences in exon II and III. The IGF-I probe was constructed from exons I, II, and III and consisted of 380 base pairs (see Rotwein et al. [33, 34] for details concerning the IGF-I gene). (B) The antisense ${ }^{32} \mathrm{P}$-labeled 380-bp riboprobe was hybridized to total RNA (10 $\mu \mathrm{g} /$ lane) from various sources in a solution hybridization RNA-protection assay. Lane 1, human liver; lane 2, alveolar macrophages (asbestosis); lane 3, alveolar macrophages (normal); lane 4, human blood monocytes.

$(8,25-27)$. Although it is possible that alveolar macrophages release more than one progression-type growth factor, the present study demonstrates that much, if not all, of this progression-type mediator is a member of the IGF-I family, a class of molecules that includes serum IGF-I (somatomedin C) and tissue IGF-I $(29,30-32,35,48,49)$. Several lines of evidence support this conclusion. First, both the macrophage mediator and molecules of the IGF-I family have progression-type growth activity in human fibroblasts. Secondly, partially purified macrophage progression-type growth factor preparations contain a molecule with antigenic determinants recognized by both polyclonal and monoclonal anti-IGF-I antibodies (50). Furthermore, with sequential purification steps, the macrophage progression-type factor and the IGF-I-type molecule track together, such that their ratio remains relatively constant. Interestingly, the apparent molecular mass of the macrophage IGF-I is $\sim 26 \mathrm{kD}$, severalfold greater than serum IGF-I and in the range of the tissue IGF-I molecules $(31,32)$. Thirdly, the macrophage molecule displaces rIGF-I from its receptor. Fourthly, the macrophage molecule stimulates purified IGF-I receptor to exhibit tyrosine-kinase activity in a fashion similar to that of rIGF-I. Finally, the alveolar macrophages contain mRNA transcripts complementary to exons I-III of the IGF-I gene.

IGF-I family of molecules. IGF-I is a 7.6-kD single-chain nonglycosylated polypeptide composed of 70 amino acids with a pI of $8.2(49,51)$. Originally identified in serum as "nonsup- 
pressible insulin-like activity," it later became known as somatomedin $C(29,48,49,52,53)$. The IGF-I gene is composed of at least five exons and four introns located over $45 \mathrm{~kb}$ of chromosome $12(34,54)$. Current concepts of the expression of the IGF-I gene suggest it codes for at least two RNA transcripts formed by alternative splicing $(33,34)$. The IGF-IA transcript $(0.8 \mathrm{~kb}$, formed from exons I, II, III, and V) codes for a protein of 153 amino acids, whereas the IGF-IB transcript $(1.1 \mathrm{~kb}$, formed from exons I, II, III, and IV) codes for a protein of 195 amino acids $(33,55)$. Although the IGF-IA and IGF-IB mRNAs have been identified, neither protein has yet been isolated. However, comparison of the gene derived sequences of the IGF-IA and IGF-IB to the known sequence of serum IGF-I demonstrates the latter is identical to residues 49-118 of IGF-IA and IGF-IB, suggesting serum IGF-I is formed from the cleavage of precursor proteins directed by the IGF-IA and/ or IGF-IB mRNA transcripts $(33,34,55)$. Consistent with this, heterogenous IGF-I peptides have been isolated from serum (56).

It is becoming evident, however, that higher molecular mass forms of IGF-I, so-called "tissue IGF-I," do exist. In this regard, IGF-I extracted from liver has an apparent molecular mass of $30 \mathrm{kD}$ (57), IGF-I isolated from human fibroblast-culture medium has a molecular mass of $21.5 \mathrm{kD}(31)$ and a 25-kD tissue IGF-I has been purified from conditioned medium of rat Sertoli cells (32). The relationship of tissue IGF-I to the putative protein products of the IGF-IA and IGF-IB ( 17.5 and $21.8 \mathrm{kD}$, respectively) transcripts is not clear, since the apparent molecular mass of these tissue IGF-I's is greater.

IGF-I functions are thought to be primarily related to their capacity to stimulate cell replication, although they may have a functional role in cell differentiation (58). In regard to its role as a growth factor, IGF-I stimulates proliferation of a variety of mesenchymal cell types, including fibroblasts, smooth muscle cells, and chondrocytes $(48,58-61)$. In this regard, IGF-I is thought to play a major role in mediating the effect of growth hormone on tissues (58). The effect of IGF-I on cell growth has been studied in detail in fibroblast cultures where it is known to act late in the $G_{1}$ phase of the cell cycle $(48,62)$. In the context of the "dual control" concept of cell proliferation proposed by Pledger and colleagues $(23,24)$, IGF-I is considered to be a "progression" factor that will stimulate "competence" factor-primed fibroblasts to proceed through $G_{1}$ and proliferate. IGF-I interacts with its target cells through a specific receptor comprising two alpha chains $(135 \mathrm{kD})$ that bind the ligand and two beta chains $(98 \mathrm{kD})$ that span the plasma membrane and contain tyrosine kinase activity (63-66). The receptor is capable of phosphorylating tyrosine and undergoing autophosphorylation; addition of IGF-I downregulated the receptor $(67,68)$. The mechanism of how the IGF-I signal is transduced to the nucleus to induce cell growth is not known, but IGF-I can rapidly induce the c-fos gene (69) suggesting that this protooncogene may be involved.

The level of the IGF-I gene expression is thought to be regulated, in part, by growth hormone $(58,70)$. The role of IGF-I in growth and development is best illustrated by the reduced stature of central African pygmies who have low serum IGF-I levels and lack the adolescent surge of growth associated with an increase in serum IGF-I (71). In disease states, serum IGF-I is low in hypopituitarism and hypothyroidism, and increased in acromegaly, but, to date, the mole- cule has not been implicated in the pathogenesis of acquired human disease (48).

Alveolar macrophage IGF-I. The fact that human alveolar macrophages produce a tissue IGF-I-type molecule has a number of interesting implications. First, although localized to the lung, alveolar macrophages are mobile cells, and thus could represent a means of depositing this growth signal in localized areas as needed. Secondly, lung maturation is known to be dependent on growth hormone, and the lungs of individuals with acromegaly are known to be overly large (72). In this regard, although there may be several sources of IGF-I in a tissue as complex as lung, alveolar macrophage production of IGF-I may play a role in local organ growth in these disorders, as well as in normal lung growth and development. Finally, alveolar macrophages are present in exaggerated numbers in the lower respiratory tract in the fibrotic lung disorders (10). In these diseases alveolar macrophages are known to spontaneously secrete exaggerated amounts of at least two competencetype growth factors, PDGF and fibronectin $(10,13,15,22)$. Furthermore, relevant to IGF-I, alveolar macrophages from patients with interstitial lung disease spontaneously release a molecule (AMDGF) with progression-type growth activity for fibroblasts $(27,28)$. Since macrophages lavaged from individuals with these disorders provided one of the sources of material for the current study, it is very likely that alveolar macrophages from these disorders release a tissue IGF-I. Interestingly, alveolar macrophages from normal individuals express the IGF-I gene constitutively, but normal macrophages do not spontaneously release a progression-type mesenchymal growth activity (26), suggesting the level of control of release of this gene product is likely complex. Furthermore, since alveolar macrophage IGF-I appear to stimulate human lung fibroblasts to release an IGF-type molecule (73), it is possible that the signal from the IGF-I released by alveolar macrophages may be markedly amplified at the level of the target cell. Together, these observations suggest a new role for this molecule in human disease states characterized by chronic inflammation and tissue fibrosis.

\section{Acknowledgments}

We thank D. Clemmons, University of North Carolina for performing the radioimmunoassays for IGF-I, M. Rechler and L. Tseng, National Institute of Digestive Diseases and Kidney, for performing the activated charcoal assay for IGF-I binding protein and advice on the tyrosine kinase phosphorylation assays, and P. Nissley and W. Kiess for purified IGF-II, and all of these individuals for their helpful suggestions concerning this study.

\section{References}

1. Adams, D. O., and T. A. Hamilton. 1984. The cell biology of macrophage activation. Annu. Rev. Immunol. 2:283-318.

2. Takemura, R., and Z. Werb. 1984. Secretory products of macrophages and their physiological functions. Am. J. Physiol. 246:C1-C9.

3. Nathan, C. F., H. W. Murray, and Z. A. Cohn. 1980. The macrophage as an effector cell. N. Engl. J. Med. 303:622-626.

4. Nathan, C. F. 1987. Secretory products of macrophages. J. Clin. Invest. 79:319-326.

5. Leibovich, S. J., and R. Ross. 1975. The role of the macrophage in wound repair. Am. J. Pathol. 78:71-100.

6. Leibovich, S. J., and R. Ross. 1976. A macrophage-dependent 
factor that stimulates the proliferation of fibroblasts in vitro. Am. J. Pathol. 84:501-514.

7. Gillespie, G. Y., J. E. Estes, and W. J. Pledger. 1985. Macrophage-derived growth factor for mesenchymal cells. Lymphokines. 11:213-242.

8. Bitterman, P. B., M. D. Wewers, S. I. Rennard, and R. G. Crystal. 1986. Modulation of macrophage-driven fibroblast proliferation by alternative macrophage mediators. J. Clin. Invest. 77:700-708.

9. Hunninghake, G. W., J. E. Gadek, O. Kawanami, V. J. Ferrans, and R. G. Crystal. 1979. Inflammatory and immune processes in the human lung in health and disease: evaluation by bronchoalveolar lavage. Am. J. Pathol. 97:149-206.

10. Crystal, R. G., P. B. Bitterman, S. I. Rennard, A. J. Hance, and B. A. Keogh. 1984. Interstitial lung diseases of unknown cause. $N$. Engl. J. Med. 310:154-166; 310:235-244.

11. Shimokado, K., E. W. Raines, D. K. Madtes, T. B. Barrett, E. P. Benditt, and R. Ross. 1985. A significant part of macrophage-derived growth factor consists of at least two forms of PDGF. Cell. 43:277-286.

12. Martinet, Y., P. B. Bitterman, J. F. Mornex, G. R. Grotendorst, G. R. Martin, and R. G. Crystal. 1986. Activated human monocytes express the c-sis proto-oncogene and release a mediator showing PDGF-like activity. Nature (Lond.). 319:158-160.

13. Mornex, J. F., Y. Martinet, K. Yamauchi, P. B. Bitterman, G. R. Grotendorst, A. Chytil, G. R. Martin, and R. G. Crystal. 1986. Spontaneous expression of the c-sis gene and release of a platelet-derived growth factor-like molecule by human alveolar macrophages. $J$. Clin. Invest. 78:61-66.

14. Ross, R., E. W. Raines, and D. F. Bowen-Pope. 1986. The biology of platelet-derived growth factor. Cell. 46:155-169.

15. Rennard, S. I., G. W. Hunninghake, P. B. Bitterman, and R. G. Crystal. 1981. Production of fibronectin by the human alveolar macrophage: mechanism for the recruitment of fibroblasts to sites of tissue injury in interstitial lung diseases. Proc. Natl. Acad. Sci. USA. 78:7147-7151.

16. Yamauchi, K., Y. Martinet, and R. G. Crystal. 1987. Modulation of fibronectin gene expression in human mononuclear phagocytes. J. Clin. Invest. 80:1720-1727.

17. Villige, B., D. G. Kelley, W. Engleman, C. Kuhn, and J. A. McDonald. 1981. Human alveolar macrophage fibronectin: synthesis, secretion, and ultrastructural localization during gelatin-coated latex particle binding. J. Cell Biol. 90:711-720.

18. Hunninghake, G. 1984. Release of interleukin-1 by alveolar macrophages of patients with active pulmonary sarcoidosis. Am. Rev. Respir. Dis. 129:569-572.

19. Wewers, M. D., C. Saltini, S. Sellers, M. J. Tocci, E. R. Bayne, J. A. Schmidt, and R. G. Crystal. 1987. Evaluation of alveolar macrophages in normals and individuals with active pulmonary sarcoidosis for the spontaneous expression of the interleukin-1 $\beta$ gene. Cell. Immunol. 107:479-488.

20. Sisson, J., K. Yamauchi, Y. Martinet, and R. G. Crystal. 1987. Human alveolar macrophages express the tumor necrosis factor- $\alpha$ gene differently than blood monocytes. Am. Rev. Respir. Dis. 135:A209.

21. Kunkel, S. L., S. W. Chensue, M. Spengler, J. Geer, and G. I. Higashi. 1986. Dynamics of interleukin-1 (IL-1) and tumor necrosis factor (TNF) production by granuloma macrophages isolated from synchronous pulmonary lesions. Am. Rev. Respir. Dis. 133:A36.

22. Martinet, Y., W. N. Rom, G. R. Grotendorst, G. R. Martin, and R. G. Crystal. 1987. Spontaneous exaggerated release of plateletderived growth factor by alveolar macrophages of patients with idiopathic pulmonary fibrosis. $N$. Engl. J. Med. 317:202-209.

23. Pledger, J., C. D. Stiles, H. N. Antoniades, and C. D. Scher. 1977. Induction of DNA synthesis in BALB/c 3T3 cells by serum components: reevaluation of the commitment process. Proc. Natl. Acad. Sci. USA. 75:4481-4485.

24. Pledger, W. J., C. D. Stiles, H. N. Antoniades, and C. D. Scher. 1978. An ordered sequence of events is required before BALB/c-3T3 cells become committed to DNA synthesis. Proc. Natl. Acad. Sci. USA. 75:2839-2843.

25. Bitterman, P. B., S. I. Rennard, S. Adelberg, and R. G. Crystal. 1983. Role of fibronectin as a growth factor for fibroblasts. J. Cell Biol. 97:1925-1932.

26. Bitterman, P. B., S. I. Rennard, G. W. Hunninghake, and R. G. Crystal. 1982. Human alveolar macrophage growth factor for fibroblasts: regulation and partial characterization. J. Clin. Invest. 70:806822.

27. Bitterman, P. B., S. Adelberg, and R. G. Crystal. 1983. Mechanisms of pulmonary fibrosis: spontaneous release of the alveolar-macrophage-derived growth factor in the interstitial lung disorders. J. Clin. Invest. 72:1801-1813.

28. Rom, W. N., P. B. Bitterman, S. I. Rennard, A. Cantin, and R. G. Crystal. 1987. Characterization of the lower respiratory tract inflammation of non-smoking individuals with interstitial lung disease associated with chronic inhalation of inorganic dusts. Am. Rev. Respir Dis. 136:1429-1434.

29. Nissley, S. P., and M. M. Rechler. 1984. Insulin-like growth factors: biosynthesis, receptors, and carrier proteins. In Hormonal Proteins and Peptides. C. H. Li, editor. Academic Press, Inc., New York. 127-203.

30. Clemmons, D. R., L. E. Underwood, and J. J. Van Wyk. 1981 Hormonal control of immunoreactive somatomedin production by cultured human fibroblasts. J. Clin. Invest. 67:10-19.

31. Clemmons, D. R., and D. S. Shaw. 1986. Purification and biologic properties of fibroblast somatomedin. J. Biol. Chem. 261:10293-10298.

32. Smith, E. P., M. E. Svoboda, J. J. Van Wyk, A. L. Kierszenbaum, and L. L. Tres. 1987. Partial characterization of a somatomedin-like peptide from the medium of cultured rat Sertoli cells. Endocrinology. 120:186-193.

33. Rotwein, D. 1986. Two insulin-like growth factor I messenger RNAs are expressed in human liver. Proc. Natl. Acad. Sci. USA. 83:77-81.

34. Rotwein, D., K. M. Pollock, D. K. Didier, and G. G. Krivi. 1986. Organization and sequence of the human insulin-like growth factor I gene. J. Biol. Chem. 261:4828-4832.

35. Han, V. K. M., A. J. D'Ercole, and P. K. Lund. 1987. Cellular localization of somatomedin (insulin-like growth factor) messenger RNA in the human fetus. Science (Wash. DC). 236:193-197.

36. Bitterman, P., S. Rennard, C. Schoenberger, and R. G. Crystal. 1981. Asbestos stimulates alveolar macrophages to release a factor causing human lung fibroblasts to replicate. Chest. 80S:38-39.

37. Rennard, S. I., R. Berg, G. R. Martin, J. M. Foidart, and P. Gehron-Robey. 1980. Enzyme-linked immunoassay (ELISA) for connective tissue components. Anal. Biochem. 104:205-214.

38. Furlanetto, R. W., L. E. Underwood, J. J. Van Wyk, and A. J. D'Ercole. 1977. Estimation of somatomedin-C levels in normals and patients with pituitary disease by radioimmunoassay. J. Clin. Invest. 60:648-657.

39. Russell, W. E., J. J. Van Wyk, and W. J. Pledger. 1984. Inhibition of the mitogenic effects of plasma by a monoclonal antibody to somatomedin C. Proc. Natl. Acad. Sci. USA. 81:2389-2392.

40. Rosenfeld, R. G., and L. A. Dollar. 1982. Characterization of the somatomedin-C/insulin-like growth factor I (Sm-C/IGF-I) receptor on cultured human fibroblast monolayers: regulation of receptor concentrations by Sm-C/IGF-I and insulin. J. Clin. Endocrinol. Metab. 55:434-440.

41. Rosenfeld, R. G., L. A. Dollar, and C. A. Conover. 1984. Density-associated loss of functional receptors for somatomedin-C/ Insulin-like growth factor I (Sm-C/IGF-I) on cultured human fibroblast monolayers. J. Cell. Physiol. 121:419-424.

42. Hunter, W. M., and F. C. Greenwood. 1962. Preparation of iodine-131 labeled human growth hormone of high specific activity. Nature (Lond.). 194:495-496.

43. Greenstein, L. A., S. P. Nissley, A. C. Moses, P. A. Short, Y. W. 
Yang, L. Lee, and M. M. Rechler. 1984. Purification of multiplication-stimulating activity. In Methods for Prep of Media, Supplements and Substrata for Serum-free Animal Cell Culture. Alan R. Liss, Inc., New York. 111-138.

44. Zapf, J., U. Kaufman, E. J. Eigenmann, and E. R. Froesch. 1977. Determination of nonsuppressible insulin-like activity in human serum by a sensitive protein-binding assay. Clin. Chem. 23:677-682.

45. Sasaki, N., R. W. Rees-Jones, Y. Zick, S. P. Nissley, and M. M. Rechler. 1985. Characterization of insulin-like growth factor I-stimulated tyrosine kinase activity associated with the $\beta$-subunit of type I insulin-like growth factor receptors of rat liver cells. J. Biol. Chem. 260:9793-9804.

46. Zinn, K., D. DiMaio, and T. Maniatis. 1983. Identification of two distinct regulatory regions adjacent to the human $\beta$-interferon gene. Cell. 34:865-879.

47. Clemmons, D. R., and J. J. Van Wyk. 1985. Evidence for a functional role of endogenously produced somatomedin-like peptides in the regulation of DNA synthesis in cultured human fibroblasts and porcine smooth muscle cells. J. Clin. Invest. 75:1914-1918.

48. Van Wyk, J. J. 1984. The somatomedins: biological actions and physiologic control mechanisms. In Hormonal Proteins and Peptides. C. H. Li, editor. Academic Press, Inc., New York. 82-125.

49. Zapf, J., C. Schmid, and E. R. Froesch. 1984. Biological and immunological properties of insulin-like growth factors (IGF) I and II. Clin. Endocrinol. Metab. 13:3-29.

50. Cook, J. J., K. M. Haynes, and G. A. Werther. 1988. Mitogenic effects of growth hormone in cultured human fibroblasts. J. Clin. Invest. 81:206-212.

51. Rinderknecht, E., and R. E. Humbel. 1978. The amino acid sequence of human insulin-like growth factor I and its structural homology with proinsulin. J. Biol. Chem. 253:2769-2776.

52. Daughaday, W. H., K. Hall, M. S. Raben, W. D. Salmon, W. D., J. Van den Brande, and J. J. Van Wyk. 1972. Somatomedin: proposed designation for sulphation factor. Nature (Lond.). 235:107.

53. Van Wyk, J. J., M. E. Svoboda, and L. E. Underwood. 1980. Evidence from radioligand assays that somatomedin- $C$ and insulinlike growth factor-I are similar to each other and different from other somatomedins. J. Clin. Endocrinol. Metab. 50:206-208.

54. Tricoli, J. V., L. B. Rall, J. Scott, G. I. Bell, and T. B. Shows. 1984. Localization of insulin-like growth factor genes to human chromosomes 11 and 12. Nature (Lond.). 310:784-786.

55. Jansen, M., F. M. A. Van Schaik, A. T. Ricker, B. Bullock, D. E. Woods, K. H. Gabbay, A. L. Nussbaum, J. S. Sussenbach, and J. L. Van den Brande. 1983. Sequence of cDNA encoding human insulin-like growth factor I precursor. Nature (Lond.). 306:609-611.

56. Blum, W. F., M. B. Ranke, and J. R. Bierich. 1986. Isolation and partial characterization of six somatomedin-like peptides from human plasma Cohn fraction IV. Acta Endocrinol. 111:271-284.

57. Vassilopoulou-Sellin, R., and L. S. Phillips. 1982. Extraction of somatomedin activity from rat liver. Endocrinology. 110:582-588.

58. Froesch, E. R., C. Schmid, J. Schwander, and J. Zapf. 1985. Actions of insulin-like growth factors. Annu. Rev. Physiol. 47:443-467.

59. Morell, B., and E. R. Froesch. 1973. Fibroblasts as an experimental tool in metabolic and hormone studies. II. Effects of insulin and nonsuppressible insulin-like activity (NSILAs) on fibroblasts in culture. Eur. J. Clin. Invest. 3:119-123.

60. Conover, C. A., R. G. Rosenfeld, and R. L. Hintz. 1986. Hormonal control of the replication of human fetal fibroblasts: site of somatomedin-C/insulin-like growth factor I. J. Cell. Physiol. 128:4754.

61. Vetter, U., J. Zapf, W. Hert, G. Helbing, E. Heinze, E. R. Froesch, and W. M. Teller. 1986. Human fetal and adult chondrocytes. Effect of insulin-like growth factors I and II, insulin, and growth hormone on clonal growth. J. Clin. Invest. 77:1903-1908.

62. Stiles, C. D., G. T. Capone, C. D. Scher, H. N. Antoniades, J. J. Van Wyk, and W. J. Pledger. 1979. Dual control of cell growth by somatomedins and platelet-derived growth factor. Proc. Natl. Acad. Sci. USA. 76:1279-1283.

63. Ullrich, A., A. Gray, A. W. Tam, T. Yang-Peng, M. Tsubokawa, C. Collins, W. Henzel, T. Le Bon, S. Kathuria, E. Chen, S. Jacobs, U. Francke, J. Ramachandran, and Y. F. Yamaguchi. 1986. Insulin-like growth factor I receptor primary structure: comparison with insulin receptor suggest structural determinants that define functional specificity. EMBO Journal 5:2503-2512.

64. Jacobs, S., F. C. Kull, H. S. Earp, M. E. Svoboda, J. J. Van Wyk, and P. Cuatrecasas. 1983. Somatomedin-C stimulates the phosphorylation of the $\beta$-subunit of its own receptor. J. Biol. Chem. 258:9581-9584.

65. Massague, J., and M. P. Czech. 1982. The subunit structures of two distinct receptors for insulin-like growth factors I and II and their relationship to the insulin receptor. J. Biol. Chem. 257:5038-5045.

66. Rechler, M. M., and S. P. Nissley. 1985 . The nature and regulation of the receptors for insulin-like growth factors. Annu. Rev. Physiol. 47:425-442.

67. Clemmons, D. R., J. J. Van Wyk, and W. J. Pledger. 1980. Sequential addition of platelet factor and plasma to BALB/c 3T3 fibroblast cultures stimulates somatomedin $C$ binding early in cell cycle. Proc. Natl. Acad. Sci. USA. 77:6664-6668.

68. Nissley, S. P., and M. M. Rechler. 1984. Somatomedin/insulin-like growth factor tissue receptors. Clin. Endocrinol. Metab. 13:43-67.

69. Ong, J., S. Yamashita, and S. Melmed. 1987. Insulin-like growth factor I induces c-fos messenger ribonucleic acid in L6 rat skeletal muscle cells. Endocrinology. 120:353-357.

70. Mathews, L. S., G. Norstedt, and R. D. Palmiter. 1986. Regulation of insulin-like growth factor I gene expression by growth hormone. Proc. Natl. Acad. Sci. USA. 83:9343-9347.

71. Merimee, T. J., J. Zapf, B. Hewlett, and L. L. Cavalli-Sforza. 1987. Insulin-like growth factor in pygmies: the role of puberty in determining final stature. N. Engl. J. Med. 316:906-911.

72. DeTroyer, A., D. Desir, and G. Copinschi. 1980. Regression of lung size in adults with growth hormone deficiency. $Q$. J. Med. 49:329-340.

73. Bitterman, P. B., S. I. Rennard, S. P. Nissley, S. Adelberg, and R. G. Crystal. 1982. Insulin-like growth factor production by fibroblasts: stimulation by alveolar macrophage-derived growth factor. Clin. Res. 30:385A. (Abstr.) 